TITLE:

\title{
PRELIMINARY NOTES ON BENTHIC GAMMARIDEAN AMPHIPODA FROM THE ZOSTERA REGION OF MIHARA BAY, SETO INLAND SEA, JAPAN
}

$\operatorname{AUTHOR}(\mathrm{S})$ :

Nagata, Kizo

CITATION:

Nagata, Kizo. PRELIMINARY NOTES ON BENTHIC GAMMARIDEAN AMPHIPODA FROM THE ZOSTERA REGION OF MIHARA BAY, SETO INLAND SEA, JAPAN. PUBLICATIONS OF THE SETO MARINE BIOLOGICAL LABORATORY 1960, 8(1): 163-182

\section{ISSUE DATE:}

1960-05-30

URL:

http://hdl.handle.net/2433/174693

RIGHT: 


\title{
PRELIMINARY NOTES ON BENTHIC GAMMARIDEAN AMPHIPODA FROM THE ZOSTERA REGION OF MIHARA BAY, SETO INLAND SEA, JAPAN
}

\author{
KIzÔ NAGATA \\ Inland Sea Regional Fisheries Research Laboratory
}

With Plates XIII-XVII and 2 Text-figures

\section{Introduction}

With the object to consider ecologically the relations between the benthic animals found in the stomach contents of various fishes and the actual inhabitants of bottoms, we made several benthos surveys in Zostera region of Mihara Bay, Seto Inland Sea, Japan, and had a larger number of collections of bottom fauna, taken by both Eckman grab-typed sampler covered an area of 0.02 sq.m., and the bottom-layer net designed by Mr. R. KITAMORI of our laboratory, throughout the period from May 1955 to March 1957. The latter sampler, bearing a pair of sleigh-form plate for making itself easily on the bottom attached below to the lower mouth frame, $0.6 \mathrm{~m}$ wide $\times 0.3 \mathrm{~m}$ height (Text-fig. 1 ), has rather a function

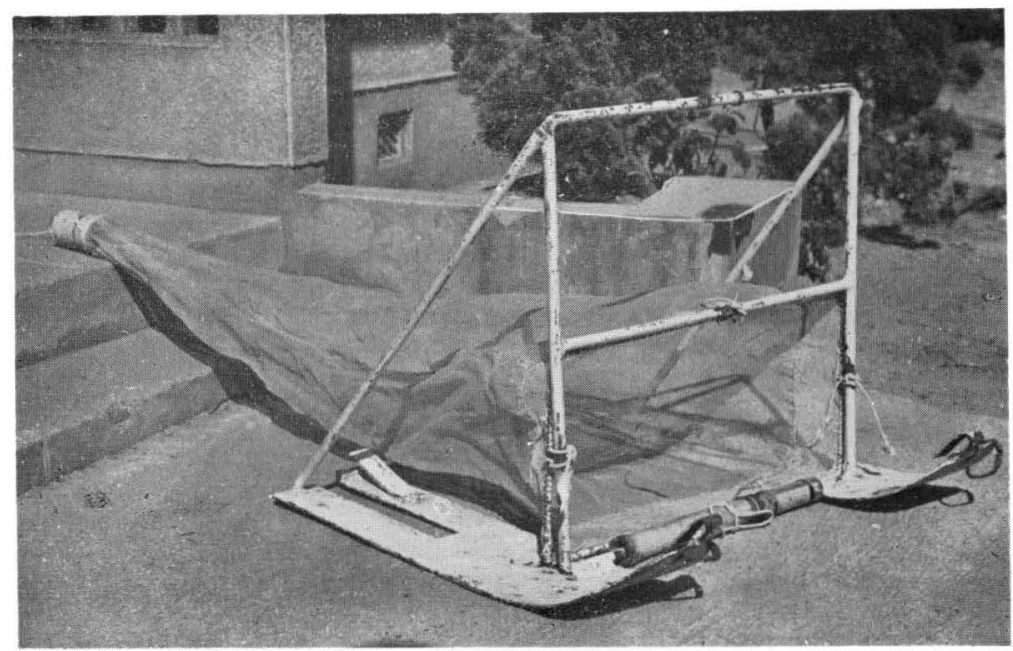

Fig. 1. The bottom-layer net employed in this survey.

Publ. Seto Mar. Biol. Lab., VIII (1), 1960. (Article 14) 
of bottom-dragging net, dragged for 30 seconds at a slowest speed of 5 miles per hour each time on board a fishing boat of 4.5 H.P., and is suitable for getting many specimens of small crustaceans, rather more epifauna than infauna.

The material of this paper is a part of the collections of the above surveys. As the survey on the enviromental condition of Mihara Bay and its ecological results are reported with detailed data by two preceding papers (KITAMORI, Kobayashi \& Nagata, 1959a and Kitamori, Nagata \& Kobayashi, 1959b), only a synopsis of the gammaridean Amphipoda is given here. The Zostera region is situated near the estuaries of Nuta River, including nine stations of Sts. 9-17 (Text-fig. 2), all nearly shallower than $3 \mathrm{~m}$ in depth at high water, except Sts. 10,12 and 13,

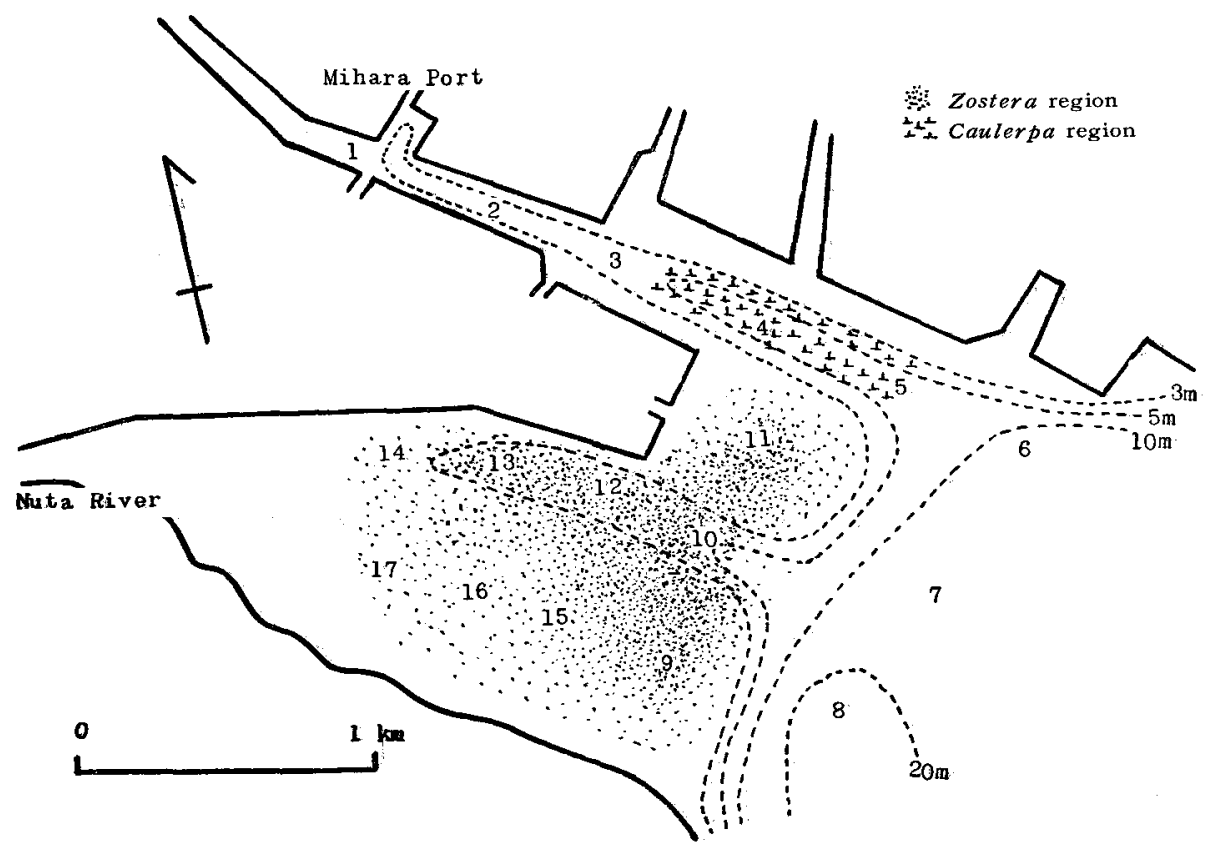

Fig. 2. Map of Mihara Bay, showing station locations of benthos survey taken by the bottom-layer net. Zostera region is dotted on Sts. $9-17$, which are concerned with the present paper.

and only a part of this region is exposed a little at low water: Water temperature at bottom layer shows an extent of about $10^{\circ}-27^{\circ}$ in centigrade, minimum in February and maximum in August. The very small variability of chlorinity at the bottom layer of about 15-18\% throughout the year, indicates no prominent influence by fresh water, while at the surface more or less effected and its influence is nearly reaching the $10 \mathrm{~m}$ isobath line at low water. All the stations in this region are occupied uniformly by muddy bottom, except Sts. 14 and 16 of sand or sandy mud. Zostera marina L. grows thickly during the period from April to June, densest especially in the area covering Sts. 9-13. 
Throughout the whole period of this survey Gammaridean amphipods are enormously abundant in number, generally ranging 60-90 percent of small crustaceans in the collections of net sampler, excluding young macrurans. Their seasonal variation seems to indicate a similar form from year to year; very few in October to December, and a very rapid rise to February and remains at the high level until June (maximum), then falls off rapidly to October again.

Most of the collections were obtained by the bottom-dragging net, covering a fairly extensive ground of $12 \mathrm{sq} . \mathrm{m}$. on an average, and their habitat condition adapted by each species, would be rather integrated horizontally. In this systematic report, 21 species are comprised and the total number of each species in all collections of nine surveys from February 1956 to March 1957, is shown as follows:

$\begin{array}{lr}\text { Anonyx ampuloides BATE } & 40 \\ \text { Orchomenella sp. } & 115 \\ \text { Ampelisca brevicornis (COSTA) } & 134 \\ \text { A. miharaensis NAGATA } & 74 \\ \text { A. naikaiensis NAGATA } & 2 \\ \text { Byblis japonicus DAHL } & 360 \\ \text { Harpinia miharaensis n. sp. } & 7 \\ \text { Pontocrates altamarinus (BATE \& WESTwOOD) } & 45 \\ \text { Pleustes panopla (KR } \text { YER) } & 126 \\ \text { Pontogeneia sp. } & 7318 \\ \text { Gammaridae gen. et sp. undet. } & 206 \\ \text { Paradexamine pacifica (THOMSON) } & 1573 \\ \text { Aoroides columbiae WALKER } & 416 \\ \text { Ampithoe lacertosa BATE } & 895 \\ \text { A. valida SMITH } & 539 \\ \text { Corophium acherusicum CoSTA } & \\ \quad \text { (together with C. insidiosum CRAWFORD } & 30 \\ \quad \text { and C. uenoi STEPHENSEN) } & 1992 \\ \text { Ericthonius pugnax DANA } & 6 \\ \text { Grandidierella japonica STEPHENSEN } & \\ \text { Podocerus sp. } & \end{array}$

Of all these species, Pontogeneia sp., Grandidierella japonica, Paradexamine pacifica, Ampithoe lacertosa and A. valida, are very common and found nearly at all stations, and especially Ampithoe two species might be said to be indicator species in this region, having never been found in any other stations of Mihara Bay. On the contrary, Anonyx ampuloides, Ampelisca brevicornis, A. miharaensis, and Byblis japonicus are relatively few in this region, except at St. 10 where the location is very complicated having various species as such in Zostera region and at the same time in the region deeper than $10 \mathrm{~m}$ depth.-Anonyx ampuloides, Ampelisca brevicornis, A. miharaensis, Byblis japonicus, Photis longicaudata, $P$. reinhardi? and Eurystheus sp. have been abundantly collected from Sts. 6-8 in a series of this survey. In rather polluted zone near Mihara Port (Sts. 1 and 2), amphipods are very scarce in number of species, only two species of Corophium 
insidiosum and Grandidierella japonica. Another paper (in preparation) will be dealt with gammaridean amphipods from other stations of this region.

I wish to thank Dr. T. Hanaoka, chief of Inland Sea Regional Fisheries Research Laboratory, for giving me an opportunity of this study and aid in preparing this paper; Mr. R. KITAMORI of our laboratory for taking his leadership of these surveys and his kind and generous help; Mr. S. Kobayashi of our laboratory for the co-operation in collecting the materials. I am very much obliged to Dr. H. Utinomi of Seto Marine Biological Laboratory, Kyoto University, for encouraging me continually and giving many valuable advices throughout the course of this work; Mr. M. Imajima of Shirikishinai Marine Biological Laboratory, Hokkaido Gakugei University and Mr. M. Kosaka of the Faculty of Fisheries, Tohoku University, who have kindly given me pertinent materials for comparison.

I am also deeply indebted to the following persons for kindly sending me many available references for this work: Dr. J. L. BARNARD of Allan Hancock Foundation, University of Southern California; Dr.T.E. Bowman of United States National Museum; Dr. D. E. HurLey of New Zealand Oceanographic Institute.

\title{
Systematics
}

\author{
Family Lisianassidae
}

\section{Anonyx ampuloides BATE}

(P1. XIII, figs. 1-6)

A. a. Stebbing 1888 , p. 308, t. 3 ; Stebbing 1906, p. 55.

Length ranging from $3 \mathrm{~mm}$ to $12 \mathrm{~mm}$. Body subcarinate. Coxa 1 considerably widened at anterior lower corner. Pleon segment 4 rather strongly depressed at dorsal profile. Eyes reniform, not greatly dilated below. Antenna 1, article 1 of peduncle slightly longer than broad, flattened on inner side, and transversely ridged in larger specimens $(12 \mathrm{~mm})$. Antenna 2, article 5 of peduncle not considerably shorter than article 4 and subequal in larger specimens. Gnathopod 1, article 6 distinctly shorter than article 5 and its hind margin considerably concave. Gnathopod 2, article 6 somewhat wider than article 5. Peraeopods 1 and 2, article 6 with a peculiar spine close to hinge of finger. Peraeopod 3, hind margin of article 2 not so concave as in STEBBing's figure. The other points are well agreed with Stebbing's diagnosis and figures.

These specimens often made me to hesitate to be identified with $A$. ampuloides as figured by Stebing, having many coincidences with $A$. nugax (PHIPPS) of arctic and boreal species, but apparently differ in having stronger depression of pleon segment 4 , shorter article 6 than article 5 of gnathopod, and relatively longer article 6 of gnathopod 2 . 
In this region, these specimens are collected nearly at St. 10. This species was recorded from Japan by STEBbing (1888).

\section{Orchomenella sp.}

(Pl. XIII, figs. 7-18)

As the writer has not been able to refer to the reports related to some important species, a diagnosis is only given here for the future specific determination.

Lateral lobe of head rather narrow in female, more narrowly produced in male as in O. minuta (KR $\phi \mathrm{YER}$ ) (SARS 1895, pl. 24, fig. 1). Coxa 1 slightly expanded along the anterior lower margin. Coxa 4 right-angularly excavated, with lower hind corner abruptly and rather narrowly upturned. Coxa 5 prominently produced downward behind as in O. pinguis (BоEсK) (SAKS 1895, pl. 24, fig. 2), but with equal breadth and depth. Pleon segment 3 with lower hind margin considerably produced, its hind margin nearly straight or slightly convex, and crenulated below with several teeth. Pleon segment 4 rather strongly depressed at dorsal profile. Eyes reniform, widened below, but nearly imperceptible in formalin. Epistome produced in a broad lobe projecting slightly beyond the upper lip. Maxilla 1, article 2 of palp with 6 spine-teeth at apex. Gnathoped 1, article 6 slightly longer than article 5, nearly not tapering to oblique and straight palm. Gnathopod 2, article 6 rather oval but with hind margin nearly straight, and about the half of article 5, produced beneath the minute finger. Peraeoped 3, article 2 shorter than the rest of the limb, its upper margin nearly straight Uropod 2, inner ramus not constricted. Uropod 3 with inner ramus subequal in length to basal joint of outer ramus. Telson rather slender, nearly twice as long as broad, and cleft extending beyond the centre.

From O. nana (KR $\mathrm{K}_{\mathrm{YER}}$ ), O. pinguis (BOECK), and O. crenata Chevreux \& FAGE, this species differs in having a characteristic epistome of broadly rounded lobe produced slightly beyond the upper lip. This rather resembles 0 . minuta ( $\mathrm{K}_{\mathrm{R}} \phi \mathrm{YER}$ ) and $O$. groenlandica $\mathrm{H}_{\mathrm{ANSEN}}$ in the form of epistome, but distinguished from the former in the shape of coxae and epimeral plate 3 , and from the latter in coxa 4, epimeral plate 3 , and uropods 2 and 3 .

The present specimens up to $12 \mathrm{~mm}$ in length, are found from nearly all stations in this region.

\section{Family Ampeliscidae}

\section{Ampelisca brevicornis (CosTA)}

A. b. Nagata 1959 , p. 69 , fig. 2 .

Up to $12 \mathrm{~mm}$ in length. These specimens are collected nearly from Sts. 9 and 
10, but some specimens from Sts. 13,15 and 16 . This species is much abundantly found below $10 \mathrm{~m}$ depth-line during these surveys, and commonly distributed in Seto Inland Sea, appearing often from the stomachs of various benthos-feeding fishes taken from all over the area.

\section{Ampelisca miharaensis NAGATA}

A. $m$. Nagata 1959 , p. 70 , figs. 3-5.

These specimens have a length up to $8.5 \mathrm{~mm}$, and are collected nearly from St. 10 in this region. This species also is abundantly found from Sts. 6-8 in a series of these surveys, and widely distibuted in offshore regions of Seto Inland Sea.

\section{Ampelisca naikaiensis NAGATA}

A. $n$. NAGATA 1959 , p. 74 , figs. $6-8$.

Two specimens, 6 and $7.5 \mathrm{~mm}$ in length, are collected only from Sts. 10 and 13. This species is very rarely found from Sts. $6-8$ during this survey, but very common in offshore area of Seto Inland Sea, appearing both from other offshore surveys and from the stomachs of bottom fishes.

\section{Byblis japonicus DAHL}

(Pl. XIII, figs. 19-23)

B. $j$. DAHL 1945, p. 14, figs. 8-10.

Up to $10 \mathrm{~mm}$ in length. Anterior margin of head has a small obtuse point (obscure in DAHL's figure). Antennae much variable in both length and breadth; antenna 1 not so long as in DAHL's specimens, about one-half of antenna 2 or less; in the peduncle of antenna 1, relative length of article 2 to article 3 much variable, ranging from $2.5 \mathrm{~mm}$ to $4.2 \mathrm{~mm}$; antenna 2 , articie 4 of peduncle distinctly longer than article 5. Telson also much variable in length, reaching about 1.5 times as long as broad in some specimens, cleft however not reaching to the middle. Uropod 1 fully reaching beyond end of uropod 2. Uropod 3 with confrontal margin of rami strongly serrate (obscure in his figure). Pleon segment 6 tricarinate. Otherwise they well agree with his specimens from Sagami Bay, Japan.

This species may be possibly distinct from B. veleronis BARNARD in broader shape of article 2 of peraeopod 3, somewhat different shape of coxae 1-4, of hind margin of pleon segment 3 , and in rather slender from of peraeopod 5 .

In this region, many specimens are collected nearly from St. 10, the other 
few from Sts. 9, 11, 12 and 14-16. This species is commonly found at Sts. 6-8, as in Ampelisca species, and also very common in the stomachs of fishes taken from offshore area in Seto Inland Sea.

\section{Family Phoxocephalidae}

\section{Harpinia miharaensis n. sp.}

(Pl. XIII, figs. 24-27 ; Pl. XIV, figs. 28-36)

Diagnosis-Hood from above narrowly rounded at apex. Posteroantennal corner with a spiniform process. Body glabrous above. Coxae 1-3 with a small tooth at lower hind corner, setae few. Pleon segment 3 with lower hind corner abruptly upturned than in $H$. pectinata SARS (1895, pl. 53, fig. 2). Gnathopod 2, article 6 slightly broader than gnathopod 1 as in pectinata. Peraeopods 1 and 2 typical. Peraeopod 3 with legs rather stout. Peraeopod 4 about one-half the length of body. Peraeopod 5 with hind margin of article 2 coarsely and deeply serrate, bearing 8 teeth of which the middle one the largest and broadly rounded - generally having a closer resemblance with pectinata in SARs' figure than that in Chevreux \& Fage's one (1925, fig. 104); article 7 relatively longer. Uropod 3 with inner ramus nearly reaching to the half of article 2 of outer ramus, which is subequal in length to article 1 of outer ramus. Telson as long as broad, tapering to obtuse apices, which are slightly dehiscent.

Remarks-The present specimens up to $3 \mathrm{~mm}$ in length, much resemble $H$. pectinata in general appearence, but I have thought it best not to designate them as that species but to create a new species for their reception; in having a small projection at postantennal corner (not produced in $H$. pectinata), the shape of hind margin of article 2 of peraeopod 5, abruptly upturned tooth at lower hind corner of pleon segment 3 , which is rather related to that in $H$. della-vallei Chevkeux (Chevreux \& Fage 1925, p. 109, fig. 103). This species is rather akin to $H$. serrata SARS in the shape of article 2 of peraeopod 5 , but differs in having a tooth at lower hind corner of coxae 1-3 (setae few), abruptly upturned tooth at lower hind corner of pleon segment 3 , the shape of downward directed points along the hind margin of article 2 of peraeoped 5 , and the from of uropod 3. This also differs from $H$. tarasovi Bulycheva (1936, p. 248, figs. 12-15; GurJanova 1951, pic. 228), in which postantennal corner without any process; pleon segment 3 with lower hind corner slightly upturned into an acute tooth; article 2 of peraeoped 5 with more downward hind lobe, denticles along its hind margin strongly and acutely serrate; and uropod 3, both inner ramus and article 2 of outer ramus relatively shorter.

In this region, this species is secured from Sts. 9, 15 and 16. In outside of this region, I have taken several specimens from St. 6. And also from the stomachs of fishes taken in Seto Inland Sea, I have occasionally had several Harpinia 
specimens, which are somewhat different from the form of the present specimens. $H$. miharaensis is named for its distinction from them.

\section{Family Oedicerotidae}

\section{Pontocrates altamarinus BATE \& WESTWOOD}

(Pl. XIV, figs. 37-45)

P. altamarinus SARs 1895, p. 695, suppl. t. 7, fig. 2 ; Stebbing 1906, p. 240.

?P. arenarius ChevreuX \& FAGE 1925, p. 240.

According to the index of species in Barnard (1958), P. norvegicus BOECK has been identified with $P$. arenarius (BATE). Therefore $P$. arenarius in ChevReUx \& FAGE (1925), may be possibly identical with $P$. altamarinus, but a doubtfulness still remains; in the former figures, antenna 1 not much longer than antenna 2, article 2 of gnathopod 2 relatively longer, apex of telson rounded. I am not quite certain that the present specimens are designated under $P$. altamarinus, having also considerable agreements with Chevreux \& FAGE's figures and diagnosis of $P$. arenarius.

These specimens, however, are considerably divergent from European forms. Eyes oblong oval. Postantennal corner more produced and curved. Antenna 1 much shorter than antenna 2 in female, as in SARS' figure. Coxae 5 and 6, anterior lobe much larger than posterior one. Molar of mandible as in CHEvREux \& FAGE's figure. Maxilla 1, inner plate with only one seta. Gnathopods as in Chevreux \& Fage's figures: gnathopod 1, article 4 produced into a rather acute projection, process of article 5 with a small spine at apex; gnathopod 2, article 2 relatively longer and slender, process of article 5 nearly coalesced with article 6. Peraeopods 1 and 2, finger considerably longer, about the half of article 6 . Peraeopod 5 with hind margin of article 2 slightly concave, article 6 subequal in length to article 5 and to article 7, as in SARs' figure. Apex of telson a little sinuated as in SARS' figure.

From $P$. arcticus SAks and $P$. arenarius (BAte) (non Chevreux \& Fage 1925), this is apparently distinguished by the structure of gnathopods, having much longer antenna 2 than antenna 1 in female, and having a slightly sinuated apex of telson.

In this region, these are collected from Sts. 12-17. This species is very commonly founded in the stomachs of fishes taken all over the area of Seto Inland Sea.

Family Pleustidae

Pleustes panopla (KR $\phi \mathrm{YER})$

(Pl. XIV, figs. 46-49) 
Pleustes panoplus SARS 1895, p. 344, t. 121 ; STEBBING 1906, p. 310.

P. cataphractus GURJANOva 1951, pic. 434.

P. obtusirostris GURJANOVA 1951, pic. 435.

P. obtusirostris GurJanova has been identified with $P$. cataphractus (STIMPSON) by Gurjanova (1951), which has also been referred to $P$. panopla by Shoemaker (1955). Length of specimens ranging $3-13 \mathrm{~mm}$. Body dorsally quinquecarinate; medio-dorsal carina weak or imperceptible on the begining of peraeon, strongly raised from peraeon segment 5 to pleon segment 2, which also have dorso-lateral carina (preceding outwards) well developed in spine-like form; pleon segments 3-6 flattened dorsally, on pleon segment 3 with 3 longitudinal rows of keel, and pleon segments 4 and 6 with 2 rows on each side; dorso-lateral carina also nearly imperceptible on the beginning of peraeon; lateral carina extending along the bases of the coxal plates and slightly continued on pleon segments 1 and 2 . Rostrum rather truncate at apex as in P. obtusirostris, but lateral lobe of head not so acute and broadly convex. Coxa 1 considerably smaller than coxa 2 . Coxa 4 rather more slender than that of SARs' figure. Peraeopod 3-5, article 2 slightly widening downward and broadly rounded at lower hind corner; article 4 short and broad, but not so prominent as that of P. depressus (Alderman 1936, fig. 14). Pleon segment 3 with lower hind corner triangularly produced and rather acute. Telson slightly constricted at base. The other points nearly as in SARs' figures.

In Mihara Bay, this species is not found from the outside of the Zostera region during these surveys.

\section{Family Pontogeneiidae}

\section{Pontogeneia sp.}

$$
\text { (Pl. XIV, figs. 50-53; Pl. XV, figs. 54-71) }
$$

If following Schellenberg's key and diagnosis (1929), the present specimens are fallen into the genus Ponotogeneia by a combination of the following characteristic points ; accesory flagellum of antenna 1 squamiform, article 5 of gnathopods elongate as in that of article 6 , and inner plate of maxilla 1 with only 6 pulmose setae, as in that of P. inermis (KR $\phi \mathrm{YER}$ ) (SARS 1895, pl. 159). The present specimens closely resemble $P$. rostrata GurJanova, but, unfortunately, I have not been able to consult with his text, and therefore the description is given here for the future decision.

Description of male, $6 \mathrm{~mm}$ in length-Dorsally smooth, back evently rounded. Rostrum prominent, produced slightly downward, about the half of length of first peduncular joint of antenna 1. Lateral lobe broadly rounded as in P. bartschi Shoemaker (1948, fig. 1). Coxa 4 similar to $P$. inermis in shape, but more broad. Pleon segments 1 and 2, epimeral plates as in inermis; that of pleon segment 3, 
lower hind corner obviously with a tooth or scarcely produced, its lateral margin much convex and rounded.

Antenna 1 shorter than antenna 2; article 1 of peduncle much stouter and longer than article 2 , which also longer than article 3 ; calceoli present only on under surface of article 2 and 3; flagellum 34-jointed and every second joint after first 4 joints is slightly produced as in STEPHENSEN's discussion (1927, p. 317 ) and with a bundle of setae; accessory flagellum shows "Kurz schuppenförmig" in Schellenbekg's description (1929) and therefore without free accessory.flagellum connected with it by an articulation. Antenna 2 reaching nearly to pleon segment 3 ; two distal articles of peduncle subequal in length, sometimes artible 4 the larger; article 4 and 5 also with calceoli on confrontal edges, and none on the rest of peduncular joints and both flagella; flagellum 43-jointed and all segments equal in shape.

Mandible normal; palp strong, article 2 of it much stouter as in $P$. bartschi; cutting edge narrow with 7 dentices ; molar strong; accessory plate not perceptible; spine-row of 5 spines. Upper lip rounding and symmetrical, and not emarginate. Epistome with the apex projecting into a narrow lobe, rather as in shape of Paramoera koreana Stefhensen (1944, fig. 4). Lower lip with small inner lobes. Maxilla 1, article 2 of palp very stout, armed distally with 7 slender teeth and several setae; outer plate with 6 serrate teeth; inner plate broad and short with 6 well developed plumose setae. Maxilla 2, inner margin of inner plate bearing well developed plumose setae as in $P$. longleyi Shoemaker (1933, fig. 6). Maxillipeds, inner plate reaching to the end of article 1 of palp and its apex with 3 spine-teeth, inner margin with slender spines and setae; outer plate not reaching end of article 2 of palp, with slender spines on the apex; article 3 of palp produced over base of finger.

Gnathopods rather slender and nearly equal in size and shape; article 6 rather longer than article 5 , palm oblique, and defined by 3 spines from hind margin; article 5 much longer than wide, and not produced forward at posterodistal corner. Peraeopods 1 and 2, articles 4,5 and 6 with a row of pulmose setae on the hind margin. Peraeopods 3-5 succesively larger, lower hind corner of article 2 moderately produced into a rounded lobe. Uropods 1 and 2 , outer ramus much shorther than inner; uropod 1 reaching beyond end of uropod 2. Uropod 3, rami lanceolate, much fringed with spines and pulmose setae on both side; outer ramus slightly shorter than inner. Telson about 1.5 times as long as broad, upper hollowed, cleft beyond the middle; lobes rather dehiscent, narrowly rounded at apices, and with submarginal setules.

Female shows no apparent differences from male, except in having no calceoli on confrontal margin of peduncle of antennae and relatively shorter antenna 2 .

Remarks-These specimens up to $8 \mathrm{~mm}$ in length, are closely related to $P$. inermis $\left(\mathrm{K}_{\mathrm{K}} \phi \mathrm{YER}\right)$ in general appearence, but differ in rather stouter form of 
nearly all of appendages, especially in gnathopods, telson, and coxa 4 .

This species is much abundantly found at all stations of this region. In outerside of the region, there are very few from Sts. 3-8.

\section{Family Gammaridae}

Gen. et sp. undet.

(Pl. XV, figs. 72-79; Pl. XVI, figs. 80-92)

Description of female, $5.5 \mathrm{~mm}$ in length-Body compressed, dorsally smooth. Coxae continuous and small; coxae 1-4 with a small tooth at anterior lower corner, coxa 4 also with a small groove at the middle of lower margin and not excavate behind. Head as long as the first two peraeon segments. Eyes rudimentary. Lateral lobe rounded. Postantennal corner less distinct. Antenna 1 slender, much longer than antenna 2 ; article 1 of peduncle about as long as head, considerably broad, and slightly longer than article 2 ; accessory flagellum small, one-jointed and shorter than the first segment of primary flagellum, which is much longer than peducle of antenna 1, 19-jointed. Antenna 2 reaching beyond peduncle of antenna 1 ; article 4 of peduncle slightly longer than article 5 ; flagellum subequal in length to article 5 of peduncle, with 4 joints plus 1 rudimentary one.

Mandible without spine-row ; molar well developed ; palp much slender, article 3 slightly longer than article 2 , with 3 long and broad setae at distal end. Maxilla 1 , inner plate very narrow with 2 setae; outer plate with 8 spines; article 3 of palp slightly widened towards the distal edge, and longer than article 2. Maxilla 2 , inner plate not fringed along inner margin; outer plate with 2 rather long setae closely at distal end. Anterior lip apically incised, with one pair of produced lateral angle. Posterior lip with inner lobes well developed. Maxillipeds with outer plate not very broad.

Gnathopod 1 slightly smaller than gnathopod 2, and similar in shape to it, except that article 5 without produced posterolateral lobe; article 6 triangular, widening to the palm, which is slightly convex, lined with several spinules, and defined from the hind margin by 6 relatively longer slender spines; finger smooth at inner edge and without nail. Gnathopod 2, article 2 rather stouter than gnathopod 1; article 5 with posterolateral margin produced into a broad lobe; article 6 slightly more elongated triangular than that of gnathopod 1. Peraeopods 1 and 2 similar in both size and shape. Peraeopods 3-5 progressively larger; article 2 of peraeopeds 3 and 4 with hind margin straight and not produced downwards; peraeopod 5, article 2, posterior lobe somewhat expanded, with its margin convex and with its lower hind corner rounded, slightly produced downwards. Uropod 1 reaching beyond end of uropod 2 ; peduncle shorter than 
rami; outer margin of peduncle with a strong spine; rami subequal in length Uropod 2, rami longer than peduncle and subequal in length. Uropod 3 projecting much beyond the others; outer ramus much longer than inner ramus, with 2 articles of which article 2 narrow and shorter than inner ramus; inner ramus small, oval and about one-third as long as article 1 of outer ramus. Telson small, shorter than peduncle of uropod 3, subequal in length to broad, and cleft nearly to base; apices much dehiscent (not so in figure), each lobe rather pointed. Pleon segment 3 with lower hind corner upturned to a tooth; its hind margin nearly straight.

Male shows no prominent sexual differences, except having much produced anterior lower corner of coxa 1, and relatively rather longer article 1 of outer ramus of uropod 3.

Remarks - The present specimens up to $5.5 \mathrm{~mm}$ in length. This species seems to be allied to the genus Nipharugus (cf. STEBBING 1906, p. 405), but differs in rather different structure of oral parts, and a broadly produced hind lobe of article 5 of gnathopod 2. From the genus Melita, this apparently differs in the structure of gnathopods.

In this region, these specimens are collected at nearly all stations, except Sts. 14 and 17. From the outerside of this region, these are found at Sts. 5 and 7.

\section{Family Dexaminidae \\ Paradexamine pacifica (ThOMson)}

(P1. XVI, figs. 93)

Dexamine pacifica THOMson 1879, p. 238, t. 10B, fig. 4.

Paradexamine pacifica StebBing 1906, p. 518; StePhensen 1927, p. 345, fiigs. 21, 22 ; BARNARD 1930, p. 389, fig. 49 ; Schellenderg 1931, p. 209.

The present specimens up to $6 \mathrm{~mm}$ in length, have nearly perfect agreement with Stephensen's figure, except in the shape of article 2 of peraeopod 4 of which hind margin abruptly narrowed towards the distal end. The confrontal margin of peduncle of antennae in male, as in BARNARD's remarks and figure, but the arrangement of spine-setae on the hind margin of article 2 of peraeopod 5 should not be characteristic of only male, though his specimens are composed of only male, and the specimens at hand, present also in female.

This species closely resembles $P$. fissicauda Chevreux (1906, p. 82, figs. 1, 2), but apparently differs in the lateral lobe of head produced into an acute point, the apices of telson truncated with several small denticles, and relative length of article 6 of peraeopods 3-5. Uropod 3 in all specimens at hand, is extending well beyond the apex of telson, as in STEPHENSEN's and BARNARD's papers, but Thоmson's not so. 
This is abundantly collected from all the stations of this region. In the outside of this region, this is found at nearly all of the stations, except Sts. 1 and 2 , but there are a few at each station.

\author{
Family Aoridae \\ Aoroides columbiae WALKER \\ (Pl. XVI, figs. 94)
}

A. columiae WAlker 1898, p. 285, pl. 16, figs. 7-10; Stebbing 1906, p. 586 ; BarNaRd 1954, p. 24, pl. 22.

A. californica Alderman 1936, p. 63, figs. 33-38.

A. californica Alderman has been identified with $A$. columbiae Walker by BARNARD (1954). The present specimens up to $5 \mathrm{~mm}$ in length. In male gnathopod 1, the shape of coxa 1, relative length of articles of limb and its shape, and setae condition in its abundance, are much variable in correspondance with their growth series, as in BAkNARD's discussion of 1954 . The posterior notch of coxa 1 is indistinct in any specimens at hand, and its anterior spine well developed in $4 \mathrm{~mm}$ specimens. The pronounced lateral lobe of hand and feeble palp of mandible are as in Alderman's specimens. Antenna 1 with accessory flagellum rudimentary, bearing 2 setae as in BARNARD's figure. Antenna 2 with flagellum bearing 3 articles, sometimes plus 1 rudimentary one.

This species is commonly founded particularly from Sts. 15 and 16 . I have also several species from Sts. 4, 5, 7 and 8 in the outer side of this region.

\title{
Family Ampithoidae \\ Ampithoe lacertosa BATE
}

(Pl. XVI, figs. 95-96)

Ampithoe lacertosa Stebbing 1906, p. 633 ; Della Valle 1893, t. 57, f. 37 ; Barnard 1954, p. 31 , pls. 29,30 .

Amphithoe macrurus StePhensen 1944, p. 80, figs. $30,31$.

Amphithoe macrurus Stephensen from Port Shimizu, Shizuoka Prefecture, Japan, has been identified by BARnard (1954) with A. lacertosa BAte. The present specimens entirely agree with BARNARD's description and figures. In BARNARD's specimens based on $24 \mathrm{~mm}$ male, article 6 of gnathopod 1 shorter than article 5 (p. 32 , pl. 29B), but is more younger specimens at hand $(11 \mathrm{~mm}$, male), they are subequal in length as in STEPHENSEN's specimens ( $13 \mathrm{~mm}$, male), though $23 \mathrm{~mm}$ specimens at hand show as BARNARD's description.

Dr. BARNARD gives several fine figures of only male specimens, and female 
figures of only gnathopods are given here. This species is easily distinguished from the next described $A$. valida Sмiтн, even in female, by the structure of article 6 of gnathopod 1, the rather stouter legs of peraeopods 1 and 2, the shape of article 2 of peraeopods $3-5$, and a small rounded tooth at lower hind corner of pleon segment 3 .

Northern Japanese specimens of this species, which has been kindly sent to me by Mr. M. Imajima of Shirikishinai Marine Biological Laboratory, Hokkaido, are shown by a cheliform component of male gnathopod 2 even in $18 \mathrm{~mm}$ long specimens, as in BARNARD's figure of $27 \mathrm{~mm}$ long specimens. (pl. 29F).

The specimens at hand up to $25 \mathrm{~mm}$ in length, are very common in this region, and has never been found in any other stations of the outer side of this region, throughout the whole period of this survey.

\section{Ampithoe valida SмITH}

(P1. XVI, figs. 97-98)

Ampithoe valida StebBing 1906, p. 635 ; Alderman 1936, p. 68 ; Barnard 1954, p. 34, pl. 31. Amphithoe shimizuensis STEPHENSEN 1944, p. 77, figs. 28, 29.

A. shimizuensis Stephensen from Japan, also has been referred to A. valida SMith in the same Barnard's paper. Dr. Baknakd says that his specimens differ from Stephensen's ones only by the shape of gnathopod 1 in both sexes, while my specimens are quite conform to BARNARD's figures. Female figures of gnathopods also is given here by the writer. The apex of telson is as in BARNARD's discussion with cover-glass, though it is rounded as in ALDERMAN's description. Female specimens of this species is characterized mainly from $A$. lacertosa, by the form of article 2 and 6 of gnathopod 1, the rather inflated shape of article 4 of peraeopods 1 and 2, the rounded shape of article 2 of peraepod 3 , and a small projection at posterodistal corner of article 2 of peraepods 4 and 5 .

A. mitsukuri Della Valle from Japan, may be possibly identical with $A$. valida, considering only from his figures (1893, t. 57, figs. 30-32; Stebring 1906, p. 635), but I am not certain as yet. This species clearly differs from $A$. japonica STEBbing in the structure of male gnathopod 2; some of the latter specimens from the stomachs of Sebastes inermis Cuvier ET VALenciennes taken in Matsushima Bay, northern Japan, have been kindly sent to me by Mr. M. KosaKA of Tohoku University, and their male gnathopod 2 well agrees with GurJanova's figure (1951, pic. 621); the latter is recorded from Kobe Bay, Seto Inland Sea by Stebing (1888), but the writer has not encountered as yet from the same area. 


\section{Family Corophiidae}

In this region, the genus Corophium is represented by the following 3 species; C. acherusicum, C. insidiosum and C. uenoi. All belongs to the section B (CRAwFORD 1937) in which urosome segment fused, and uropods 1 and 2 inserted in the lateral margins of the urosome. As on the beginning of this survey these species, unfortunately, has been labeled and put together into the same bottle, as a single species of $C$. acherusicum by only a superficial appearence, the number of these specimens listed in the introduction, are shown as their total counts composed of 3 species.

\section{Corophium acherusicum CosTA}

C. acherusicum Chevreux \& FAGE 1925, p. 368, fig. 376 ; Crawford 1937, p. 617, fig. 2-P; Shoemaker 1947, p. 53, figs. 2, 3 ; Hurley 1954, p. 442, figs. 35-39.

Length up to $5.5 \mathrm{~mm}$. This species is commonly found in this region. Article 1 of antenna 1 with basal spine on inner and under margin often recurved as in C. bonelli SARs. Arrangement of spines on antennae in female is considerably variable. Its variation of the number of spines on the right antennae of 11 specimens extracted at random is shown as follows (the additional spines borne alongside an original pair, are added into its pair) :

\begin{tabular}{|c|c|c|c|c|c|c|}
\hline \multirow{2}{*}{\multicolumn{3}{|c|}{ Length }} & \multicolumn{2}{|c|}{ Antenna 1, article 1} & \multicolumn{2}{|c|}{ Antenna 2} \\
\hline & & & Inner margin & Under margin & Article 4 & Article 5 \\
\hline $3.0 \mathrm{r}$ & $\mathrm{nm}$. & ovig. & $4^{*}$ & $5^{*}$ & $2,2,2,1$ & 2 \\
\hline 3.0 & $"$ & - & 4 & 5 & $2,2,2,1$ & 2 \\
\hline 3.5 & $"$ & ovig. & 5 & $6^{*}$ & $2,2,2,1$ & 2 \\
\hline 4.0 & $"$ & $"$ & $5^{*}$ & $5^{*}$ & $1,3,2,2,1$ & 2 \\
\hline 4.2 & $"$ & $"$ & $4^{*}$ & $7^{*}$ & $2,2,2,1$ & 2 \\
\hline 4.2 & ” & " & 4 & 5 & $2,2,2,1$ & 2 \\
\hline 4.2 & $"$ & " & 5 & 5 & $2,2,2,2,1$ & 3 \\
\hline 4.5 & " & $"$ & $5^{*}$ & $6^{*}$ & $2,2,2,1$ & 2 \\
\hline 4.5 & $"$ & $"$ & 4 & $7^{*}$ & $2,2,2,1$ & 2 \\
\hline 4.5 & ” & $"$ & 4 & $6^{*}$ & $1,2,2,2,1$ & 2 \\
\hline 5.5 & $"$ & $"$ & $5^{*}$ & $7^{*}$ & $2,2,2,1$ & 2 \\
\hline
\end{tabular}

This species is distinguished from the other 2 species in this region, by the following characters; in female, typically having 3 pairs of spines and a single terminal spine on segment 4 of antenna 2 ; in male, easily by having a short rostrum, and a small process near the base on article 5 of antenna 2 .

\section{Corophium insidiosum CRAWFORD}

C. insidiosum Crawford 1937, p. 615, figs. 2, A-G; Shoemaker 1947, p. 53, figs. 6-7. 
This species also is very common in this region, as C. acherusicum. The present specimens up to $4.7 \mathrm{~mm}$, apparently differ from female of C. bonelli in having a basal straight spine on inner and under margin of article 1 of antenna 1 ; from male in having a long rostrum. The number of spine on article 1 of antenna 1 , is considerably variable, and shown as follows by the right antennae of 9 specimens extracted at random from the mixed specimens of three species :

\begin{tabular}{|c|c|c|c|c|c|}
\hline \multirow{2}{*}{\multicolumn{2}{|c|}{$\begin{array}{c}\text { Length } \\
3.0 \mathrm{~mm} \text {, ovig. }\end{array}$}} & \multicolumn{2}{|c|}{$\begin{array}{l}\text { Antenna 1, article } 1 \\
\text { Inner margin } \\
\text { Under margin }\end{array}$} & \multicolumn{2}{|c|}{ Antenna 2} \\
\hline & & & & 201 & 1 \\
\hline 3.2 & $" \quad "$ & 2 & 3 & $2,2,1$ & 1 \\
\hline 3.2 & $"$ & 3 & 3 & $2,2,1$ & 1 \\
\hline 3.5 & " & 3 & 3 & $2,2,1$ & 1 \\
\hline 4.0 & $"$ & 3 & 4 & $2,2,1$ & 1 \\
\hline 4.0 & $"$ & 3 & 4 & $2,2,1$ & 1 \\
\hline 4.2 & $"$ & 2 & 3 & $3,2,1$ & 2 \\
\hline 4.2 & $"$ & 3 & 3 & $2,2.1$ & 1 \\
\hline 4.7 & $"$ & 3 & 4 & $2,2,1$ & 1 \\
\hline
\end{tabular}

Male of this species closely resembles from the next described species, $C$. uenoi in having a long rostrum, but differs in having an outgrowth on proximal inner surface of article 1 of antenna 1, and not any spine on article 4 of antenna 2.

\section{Corophium uenoi STEPHENSEN}

C. uenoi STEPHENSEN 1932, p. 414, figs. 3-4; CRAWFORD 1937, p. 616 ; BARNARD 1952, p. 28, pls. 8,9 .

Up to $5.5 \mathrm{~mm}$ in length. This species are less found in this region, and this female is easily distinguished from female of the above 2 species by having spines set in a single row on article 4 of antenna 2 . One dissected female $(5.5 \mathrm{~mm})$ was found to have a additional spine proximally on article 4 of antenna 2. The number of spines on article 1 of antenna 1 in female also is considerably divergent from the typical number, and their basal spines are often recurved. Their conditions are as follows:

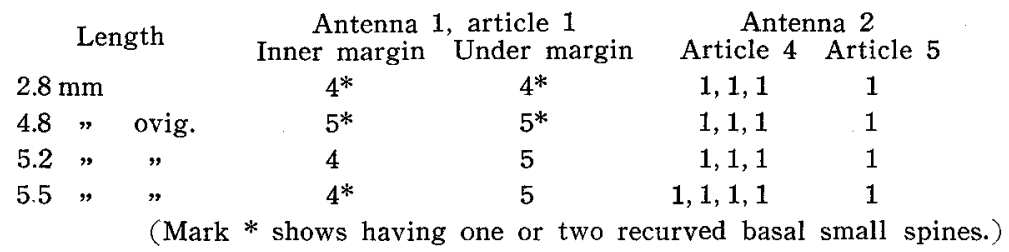

These specimens in male is rather different from the Californian specimens in BARNARD 1952, by having a spine proximally on the inner surface of article 4 of antenna 2, having not any process on proximal lower edge of article 5 of antenna 2 , and having article 2 of peraeopod 5 shorter than article 6 . 


\section{Ericthonius pugnax DANA}

(Pl. XVII, figs. 99-102)

E. pugnax Stebbing 1906, p. 672; Pirlot 1938, p. 352 ; HurLey 1954, p. 445, figs. 40-61.

Dr. Hurley has given many fine figures, and the present specimens up to $7.5 \mathrm{~mm}$ in length, well agree with his description and figures, except in the somewhat different shapes of the following points; articles 5 and 6 of male gnathopod 2 more rather elongated than that of his figure, its hind margin of article 6 sometimes with 4 small tubercles and its process of article 5 sometimes shows no prominent inner tooth; article 2 of peraeopod 3 with hind margin more produced downwards, which remembers that of E. macrodactylus DANA (WALKER 1904, pl. 7, fig. 48).

This species differs from $E$. macrodactylus DANA, in the structure of male gnathopod 2. This is also closely related to E. brasiliensis DANA and E. difformis M.-ED., but differs mainly in the shape of article 2 of peraeopods 1 and 3 respectively.

These specimens are collected at. Sts. 12, 13, 15, 16 in this region, and also from Sts. 7, 8 of the outer side of this region, are found.

\section{Grandidierella japonica STEPHENSEN}

(Pl. XVII, figs. 103)

G. japonica Stephensen 1938, p. 179, figs. 1, 2.

The present specimens up to $12 \mathrm{~mm}$ in length, have quite agreement with StepHENSEn's description and figures. The writer has, as yet, found no specimens having any short medio-ventral spine on peraeon segment 1 . Article 2 of male gnathopod 1 somewhat oblong oval rather than that in STEPHENSEN's specimens. These specimens have "stridurating organ" on upper proximal margin of article 5 of male gnathopod 1 , and also have triangular process at the upper hind corner of article 2 of peraeopods 3 and 4 .

This species is much abundantly found from all the stations in this region throughout the period of these surveys. This is also sometimes found at Sts. 1 and 2 , but not found from Sts. 3-8.

\section{Family Podoceridae \\ Podocerus sp. \\ (Pl. XVII, figs. 104-112)}

Some species in this genus are considerably related to one another, so that 
there may possibly be a certain confusion in the details of their growth-change or multiform. The present specimens closely resemble $P$. inconspicuus Stebbing (cf. Stebiing 1888, t. 131 ; Pirlot 1938, fig. 160; Barnard 1937, fig. 18) in the structure of gnathopods in both sexes. Unfortunately I was unable to refer to $P$. palinuri BARNARD in his paper of 1916 , which was identified with $P$. inconspicuus by his own paper of 1940 . These are rather related to $P$. danae (STEBBING) (Stebing 1888, t. 128,129 ) in the shape of head, having the similar lateral carina and peraeopods 1-5; and to P. cristatus (Thomson) (1879, p. 331, pl. 16, figs. 9-15) in the arrangement of dorsal carina, but conspicuously differ in the following characteristic point: in many specimens at hand of a growth series ranging from 3.5 to $8 \mathrm{~mm}$ in length, together with other localities in Seto Inland Sea, the shape and structure of article 6 of male gnathopod 2 proportionally show the same appearence, and are never shown, even in $8 \mathrm{~mm}$ specimens, such a shape of much narrowly elongated propodus respectively.

For the future decision of this species by any other authority, synopsis is given here. Body wider than deep, quinquecarinate; in the medio-dorsal line, peraeon segments 1-4 weak, but strongly corrugated, the 5th with a small projection behind, the $6 \mathrm{th}, 7 \mathrm{th}$, and pleon segments 1-2 each well developed process of carina and its shape and arrangement nearly maintain the same dorsal profile in both their growth series and sexual defference and at least never shown such a strongly acute point as in danae; in the dorso-lateral line, these are small indications of tubercles on each side, 1 to each segment, but that on the begining of the peraeon segments, rather imperceptible, back distinctly tending to pleon segment 2 ; lateral margin of peraeon projecting, with trilobes on segments $3-7$ as nearly in danae. Head ribbed as in peraeon, with fore carina rounded or truncated in front. Eyes large, rounded, and placed into rectangular lateral lobe as in danae. Antannae nearly similar to that of danae; antenna 1, flagellum with 4-7 joints, accessory one 1-jointed; antenna 2, article 5 of peduncle not so long as that in danae, flagellum 3 -jointed, the first much longer than the other 2 united, all 3 together subequal to or shorter than article 4 of peduncle, the last tipped with a strong spine.

Epistome with a small spiniform projection produced forward at distal end. Coxal plates in each segment are more or less keeled transeversely along the middle; coxa 1 much produced at the anterior lower corner. Gnathopod 1 in male, article 5 distally narrowing, shorter than article 6 , which its palm slightly concave, much longer than hind margin; article 7 serrated along the inner edge; in female, article 5 slightly longer than article 6 , which its palm subequal in length to hind margin. Gnathopod 2 in male, article 2 with anterodistal corner produced into a small rounded lobe; article 4 with the apices of hind margin slightly produced; article 5 subsquare in shape, and larger than article 4 ; article 6 more oblong oval than in female, palm having a broad lobe followed by a small 
conical tooth near the finger-hinge, and defined by a distinct tooth and a strong spine and another one spine at a little upper surface, from the short hind margin; in female, article 6 abruptly wider than article 5, and oval and the other points nearly similar to male. Peraeopods 1-5 nearly as in danae. Pleopods 1-3 each with 2 coupling spines. Uropod 3 not reaching end of telson. Telson with basic plate rounded, conical projection rising from the surface at about the centre, as in Thomson's figure.

These specimens are collected at Sts. 9, 10, 12, 15 and 16. In outer side of this region, found from Sts. 5-8.

\section{LITERATURE CITED}

Alderman, A. L., 1936. Some new and little known amphipods of California. Univ. Calif. Publ. Zool., vol. 41 , no. 7 .

BARNARD, J. L., 1952. Some Amphipoda from central California. Wasmann Jour. Biol., vol. 10, no. 1 .

1954a. Marine Amphipoda of Oregon. Oregon State Monog., Studies in Zool., no. 8.

1954b. Amphipoda of the family Ampeliscidae collected in the eastern Pacific Ocean by the Velero 3 and Velero 4. Allan Hancock Found. Pac. Expeds., vol. 18, no. 1.

BARNARD, K. H., 1927. Amphipoda. John Murray Exped., vol. 4, no. 6.

1930. Amphipoda. British Antarctic ("Terra Nova") Exped., 1910, London, Nat. Hist. Repts., Zool., vol. 8, no. 4 .

Bulycieva, A., 1936. New species of Amphipoda from the Japan Sea. Ann. Mag. Nat. Hist. ser. 10 , vol. 18 .

Chevreux, E., 1906. Diagnoses d'Amphipodes nouveaux provenant de l'expedition antarctique du Français. Bull. Soc. Zool. France, vol. 20.

Chevreux, E. \& FAge, L., 1925. Amphipodes. Faune de France, vol. 9.

CRAWFORD, G. I., 1937. A review of the amphipod genus Corophium, with notes on the British species. Jour. Mar. Biol. Assoc. U.K., vol. 21, no. 2.

DAHL, E., 1945. Amphipoda of the family Ampeliscidae from Professor Sixten Bock's Expedition to Japan, 1914. Arkiv. för. Zool., vol. 36, no. 1.

Della Valle, A., 1893. Gammarini del. Golfo di Napoli. In Fauna und Flora des Golfes von Neapel. Monog., vol. 20.

GURJAnOvA, E., 1951. Bokoplavy Morei SSSR e Sopredelnyx Vod (Amphipoda-Gammaridea). Opred. Faune SSSR, Akad. Nauk., vol. 41:

Hurley, D. E., 1954. Studies on the New Zealand Amphipodan Fauna. No. 7. The Family Corophiidae, including a new species of Paracorophium. Trans. Roy. Soc. N. Z., vol. 82, part 2.

KitAMORI, R., KoBAYASHI, S. \& NAGATA, K., 1959a. The benthic community in polluted coastal waters. (II) Mihara Bay. Bull. Naikai Regional Fish. Res. Lab., 12. (In Japanese.)

Kitamori, R., Nagata, K. \& Kobayashi, S., 1959b. The ecological study on "Moba" (Zone of Zostera marina L.). (II) Seasonal changes. Ibid., 12. (In Japanese.)

NagatA, K., 1959. Notes on five species of the amphipod genus Ampelisca from the stomach contents of the trigid fishes. Publ. Seto Mar. Biol. Lab., 7 (2).

Pirlot, J. M., 1938. Les Amphipodes de l'expedition du Siboga. Les Amphipodes Gammarides. III. Les Amphipodes Littoraux. 2. Siboga Expeditie, $33 \mathrm{f}$.

SARS, G. O., 1895. An Account of the Crustacea of Norway. 1. Amphipoda.

Schelleniberg, A., 1929. Revision der Amphipoden-Familie Pontogeneiidae. Zool. Anz. 85.

-__.._ 1931. Gammariden und Caprelliden Magellangebietes, Südgeorgien und der Westantarktis. Further Zool. Res. Swed. Antarct. Exp., 2. 
Shoemaker, C. R., 1933. Two new genera and six new species of Amphipoda from Tortugas. Carnegie Inst. Washington, Papers from the Tortugas Lab., 28.

- 1947. Further notes on the amphipods genus Corophium from the east coast of America. Jour. Wash. Acad. Sci., 37 (2).

1948. The Amphipoda of the Smithsonian-Roebling Expedition to Cuba in 1937. Smithson. Misc. Colls., 110 (3).

Stebbing, T. R. R., 1888. Amphipoda. Report "Challenger" Expedition. vol. 29.

1906. Cmphipoda. Gammaridea. Das Tierreich, 21.

Stephensen, K., 1927. Crustacea from the Auckland and Campbell Island. Vid. Medd. fra Dansk Naturh. Foren., 83.

1932. Some new amphipods from Japan. Annot. Zool. Japon., 13 (5).

1938. Grandidierella japonica $\mathrm{n}$. sp. A new amphipod with stridulating organs from brackish water in Japan. Ibid., 17 (2).

1944. Some Japanese amphipods. Vid. Medd. fra Dansk Naturh. Foren., 108.

Thomson, G. M., 1879. Addition to the amphipodous Crustacea of New Zealand. Ann. Mag. Nat. Hist., ser. 5,4 (23).

Walker,, A. O., 1898. Crustacea collected by W. A. Herdman, F. L. S., in Puget Sound, Pacific Coast of North America, Sept. 1897. Proc. Trans. Liverpool Biol. Soc., 12.

1904. Report on the Amphipoda collected by Professor Herdman, at Ceylon, in 1902.

In Herdman, Report to the Government of Ceylon on the Pearl Oyster Fisheries of the Gulf of Manaar-with Supplementary Reports., 17.

\section{EXPLANATION OF PLATE XIII}

Anonyx ampuloides Bate. Female, $6.5 \mathrm{~mm}$ : 1 - Coxa 1. 2-Pleon segment 4. 3-Gnathopod 1, together with enlarged distal edge. 4-Gnathopod 2. 5-Peraeopod 1, peculiar spine of article 6. 6-Peraeopod 3, article 2. Orchomenella sp. Female, $5 \mathrm{~mm}$ : 7-Head. 8-Coxae 4 and 5. 9-Pleon segment 3. 10-Pleon segment 4, dorsal depression. 11-Epistome. 12Maxilla 1, apex of palp. 13-Gnathopod 1, together with enlarged distal edge. 14-Gnathopod 2, setae omitted. 15-Telson. Male, $4.7 \mathrm{~mm}$ : 16Pleon segment 4, dorsal depresson. Female, $5.5 \mathrm{~mm}$ : 17-Peraeopod 3. 18Uropod 3. Byblis japonicus DAHL. Male $6 \mathrm{~mm}$ : 19-Head and peduncle of antenna 1. 22-Uropod 3. 23-Telson. Female, $7 \mathrm{~mm}: 20-$ Coxae 1-4. 21-Epimeral plate 3. Harpinia miharaensis n. sp. Female, $2.8 \mathrm{~mm}: 24$ Head with lateral and dorsal view. 25-Epimeral plate 3. 26-Antenna 1. 27-Antenna 2.

Scale A : 1, 2, 6-10, 17, 19-21. B : 3, 4, 11, 13, 14, 16, 18, 22-24, 26, 27. C : $5,12,15,25$. 
Publ. Seto Mar. Biol. Lab., VIII, 1 (1960)

PLATE XIII

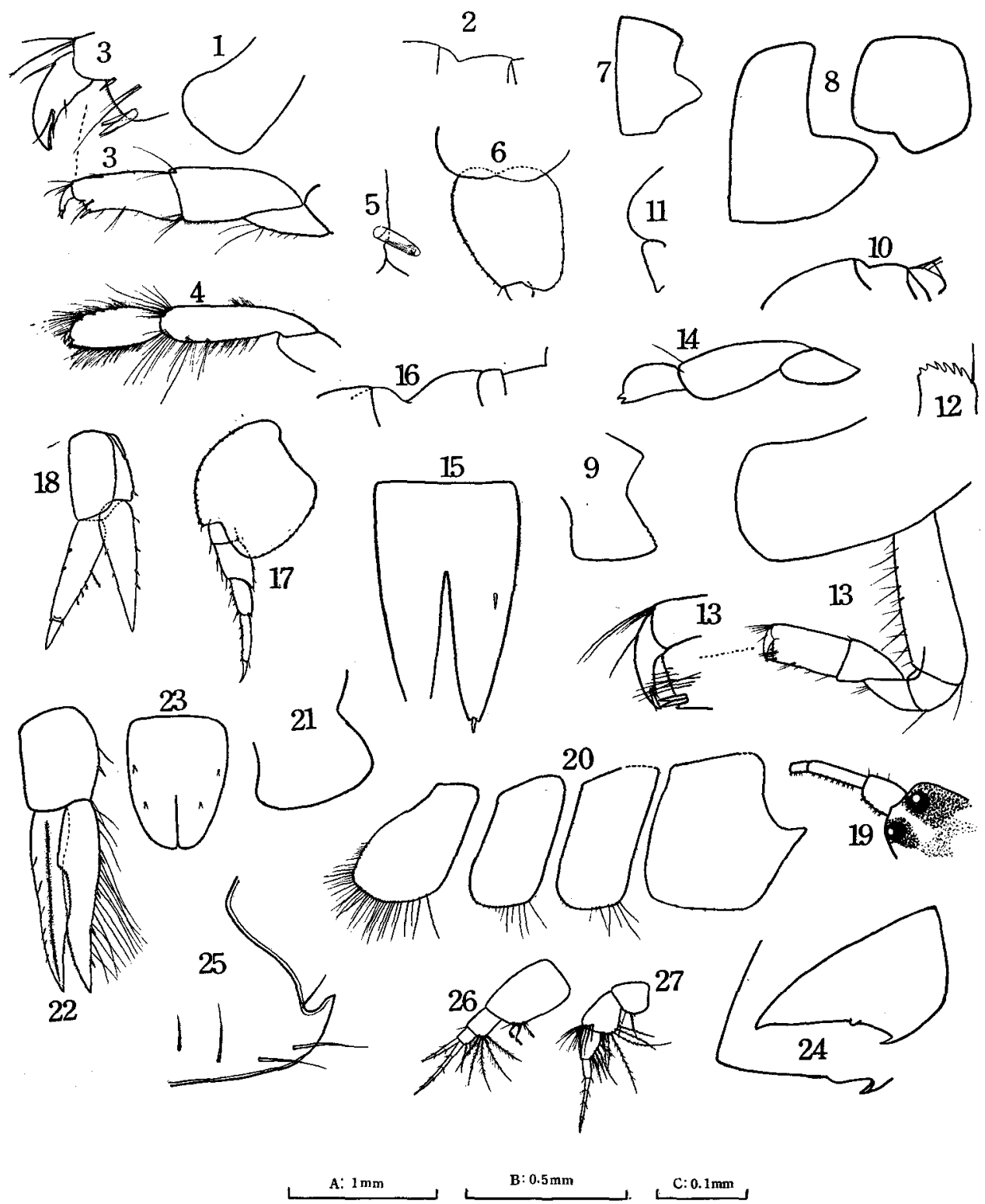

K. Nagata: Benthic Gammaridean Amphipoda from Zostera Region. 


\section{EXPLANATION OF PLATE XIV}

Harpinia miharaensis n. sp. Female, $2.8 \mathrm{~mm}$ : 28-Gnathopod 1. 29-Gnathopod 2. 30-Peraeopod 1. 31-Peraeopod 2. 32-Peraeopod 3. 33-Peraeopod 4. 34-Peraeopod 5. 35-Uropod 3. 36-Telson. Pontocrates altamarinus BAte \& Westwood. Female, $11 \mathrm{~mm}$ : 37-Head. 38-Antennae. 39-Mandible. 40-Gnathopod 1. 41-Gnathopod 2. 42-Peraeopod 1, 4-7. 43-Telson. Female, $6 \mathrm{~mm}$ : 44-Coxae 5 and 6. 45-Peraeopod 5, article articles 2. Pleustes panopla (KR $\phi \mathrm{YER}$ ). Female, $11 \mathrm{~mm}$ : 46-Head. 47Pleon seg-ments 1-3. Female, 6mm: 48-Coxae 1, 2, and 4. 49-Peraeopod 3. Pontogeneia sp. Male, $6 \mathrm{~mm}$ : 50-Head and peduncle of antenna 2. 51-Accessory flagellum. 52-Antenna 1, peduncle. 53-Antenna 1, flagellum.

Scale A : 40-42, 44-50, 52. B : 28-34, 53. C: $35,36,51$. Others $(37-39,43)$ with their own scale. 
Publ. Seto Mar. Biol. Lab., VIII, 1 (1960)

PLATE XIV

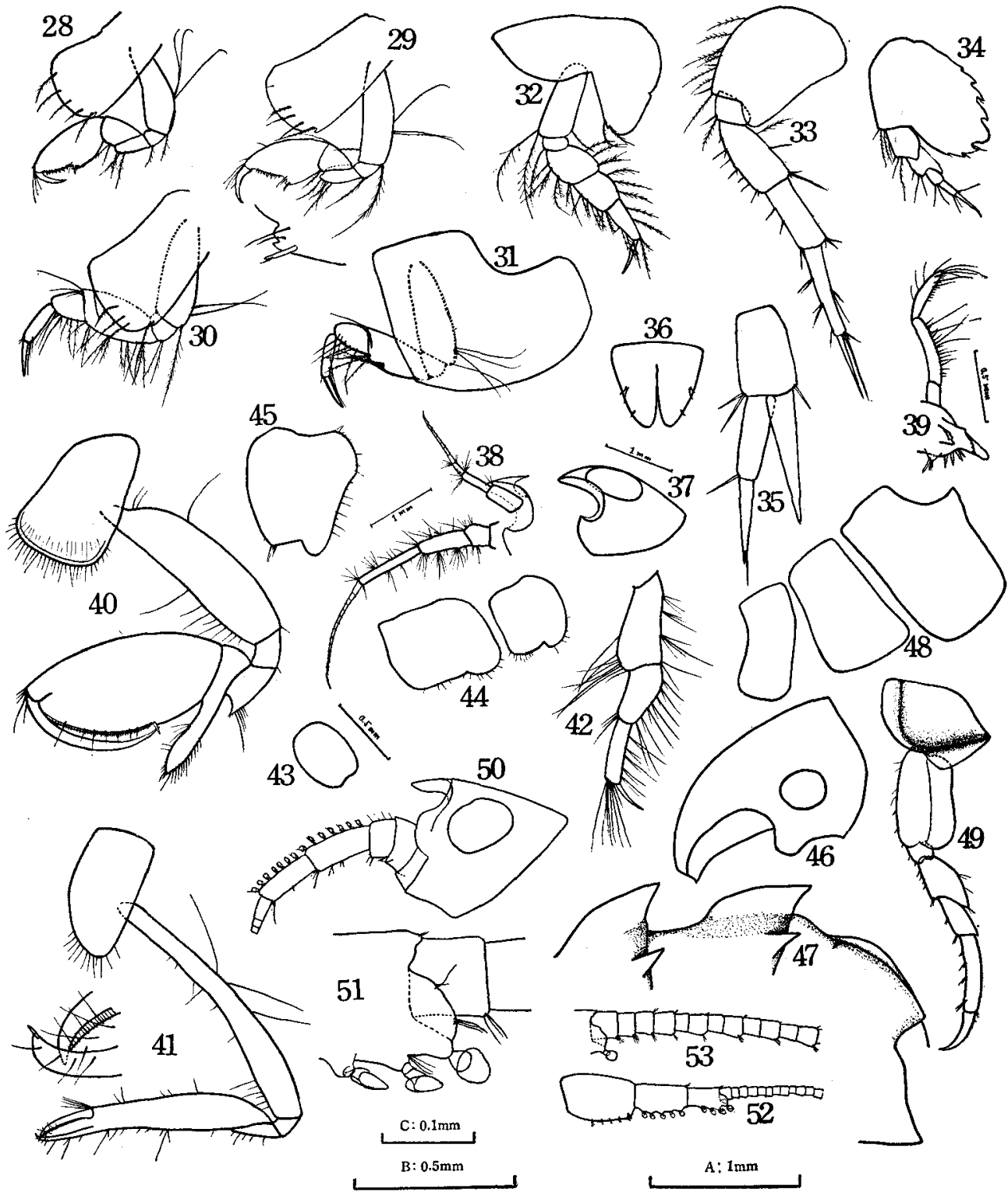

K. Nagata: Benthic Gammaridean Amphipoda from Zostera Region. 


\section{EXPLANATION OF PLATE XV}

Pontogeneia sp. Male, $6 \mathrm{~mm}$ : 54-Epimeral plates 1-3. 55-Mandible. 56-Upper lip. 57-Lower lip. 58-Maxilla 1. 59-Maxilla 2. 60-Maxillipeds. 61-Gnathopod 1. 62-Gnathopod 2. 63-Peraeopod 1. 64Peraeopod 2. 65-Peraeopod 3. 66-Peraeopod 4. 67-Peraeopod 5. 68Uropod 1. 69 -Uropod 2. 70-Uropod 3. 71-Telson. Gammaridae gen. et sp., undet. Female, $5.5 \mathrm{~mm}$ : 72-Head. 73-Anterior lip and Epistome. 74-Mandible. 75-Maxilla 1. 76-Maxilla 2. 77-Maxillipeds. 78-Gnathopod 1. 79-Gnathopod 2.

Scale A : 54, 63-67, 72. B : 55-62, 68-71, 73-79. 


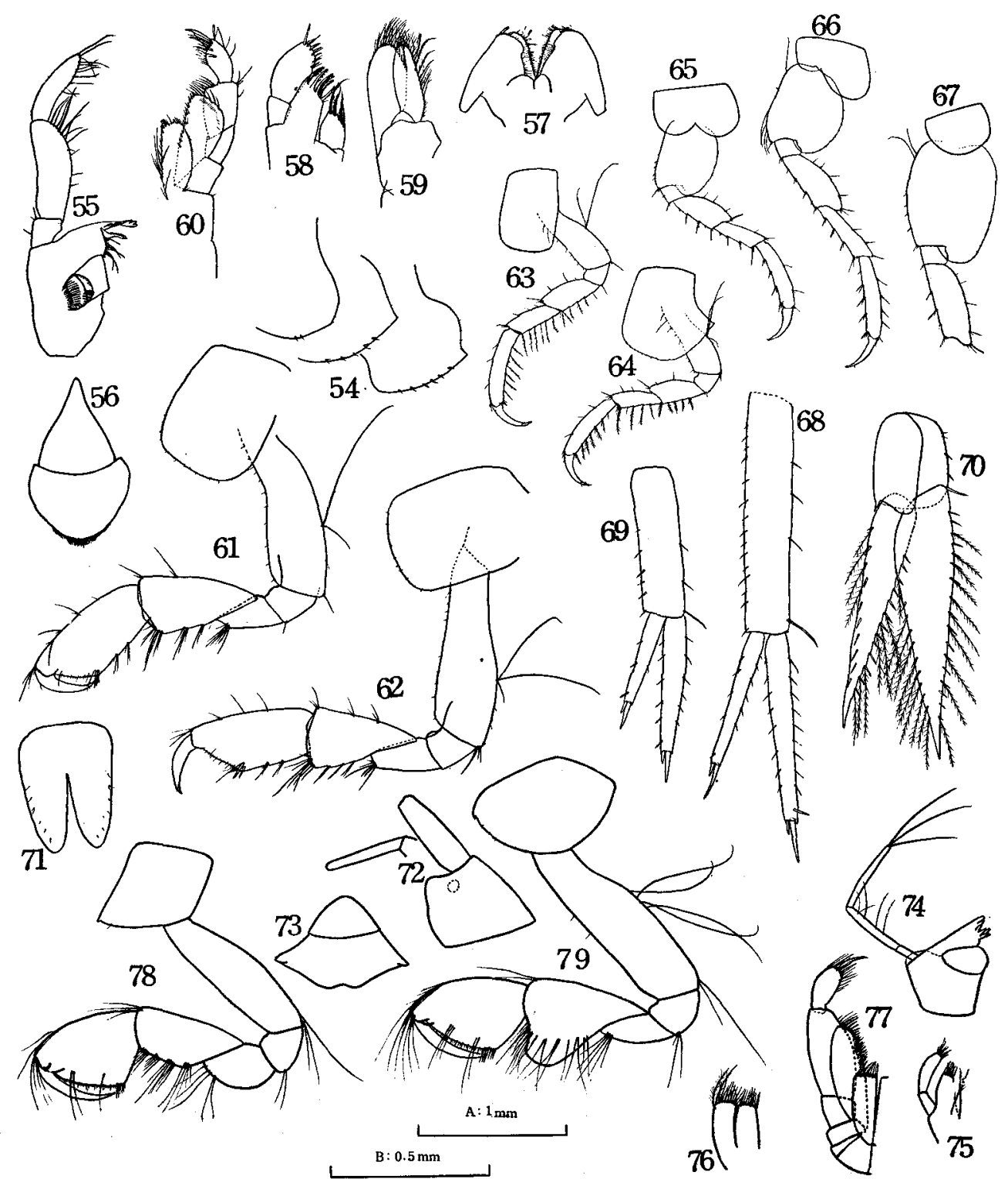

K. Nagata: Benthic Gammaridean Amphipoda from Zostera Region. 


\section{EXPLANATION OF PLATE XVI}

Gammaridae Igen. et sp. undet. Female $5.5 \mathrm{~mm}$ : 80-82-Peraeopods 3-5. 83-Pleon segment 3. 84-86-Uropods 1-3. 87-Telson. Female, $4.5 \mathrm{~mm}$ : 88-Antennae. Male, $5 \mathrm{~mm}: 89$-Accessory flagellum. 90-Posterior lip. 91Peraeopod 2. 92-Uropod 3. Paradexamine pacifica (Thomson). Male, $5 \mathrm{~mm}$ : 93-Peraeopod 4, article 2. Aoroides columbiae Walker. Male, $4 \mathrm{~mm}$ : 94-Gnathopod 1. Ampithoe lacertosa. BAte. Female, $16 \mathrm{~mm}$ : 9596-Gnathopods 1-2. Ampithoe valida Smrth. Female, $13 \mathrm{~mm}: 97$ and 98-Gnathopods 1 and 2.

Scale A : 83, 88, 93, 95-98. B : 80-82, 84-86, 90-92, 94. C : 87, 89. 
Publ. Seto Mar. Biol. Lab., VIII, 1 (1960)

PLATE XVI

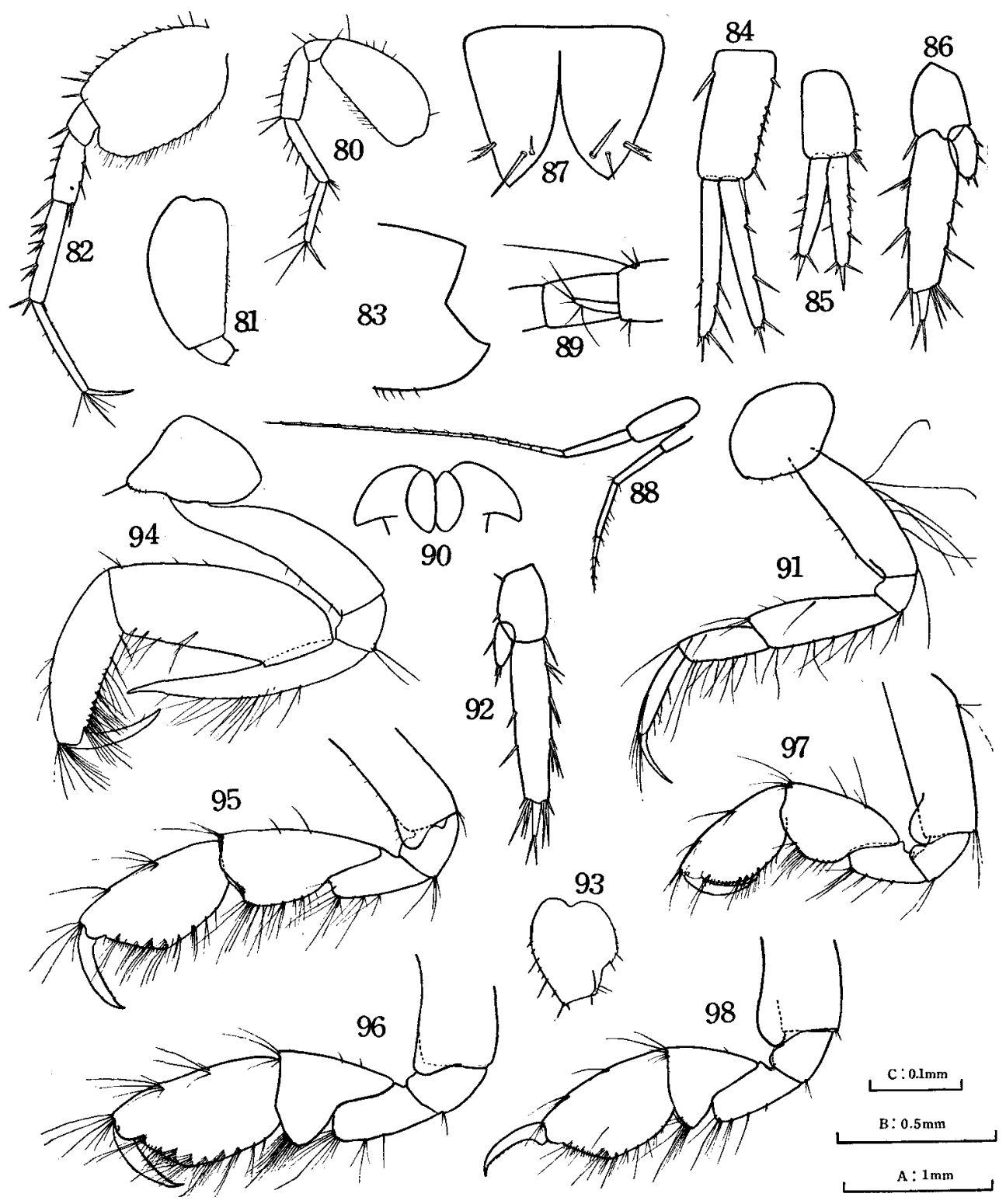

K. Nagata: Benthic Gammaridean Amphipoda from Zostera Region. 


\section{EXPLANATION OF PLATE XVII}

Ericthonius pugnax DanA. Male, $6 \mathrm{~mm}$ : 99-Gnathopod 2. 100-Peraeopod 3. Male, $6.5 \mathrm{~mm}$ : 101 -Gnathopod 2. 102-Peraeopod 1. Grandidierella japonica Stephensen, Male, $10 \mathrm{~mm}: 103$-Gnathopod 1, outside. Podocerus sp. Male, $7 \mathrm{~mm}$ : $104-$ Head, and dorsal carina from peraeon segment 1 to pleon segment 3. 105-Cross-section of peraeon segment 2. 106-Gnathopod 1. 107-Gnathopod 2. Female, $8 \mathrm{~mm}: 108$-Upper and lateral view of head. 109-Lateral lobes of peraeon segments 2, 3 and 6. 110-Gnathopod 1. 111-Gnathopod 2. 112-Telson.

Scale A : 99, 101, 103-111. B : 100, 102, 112. 
Publ. Seto Mar. Biol. Lab., VIII, 1 (1960)

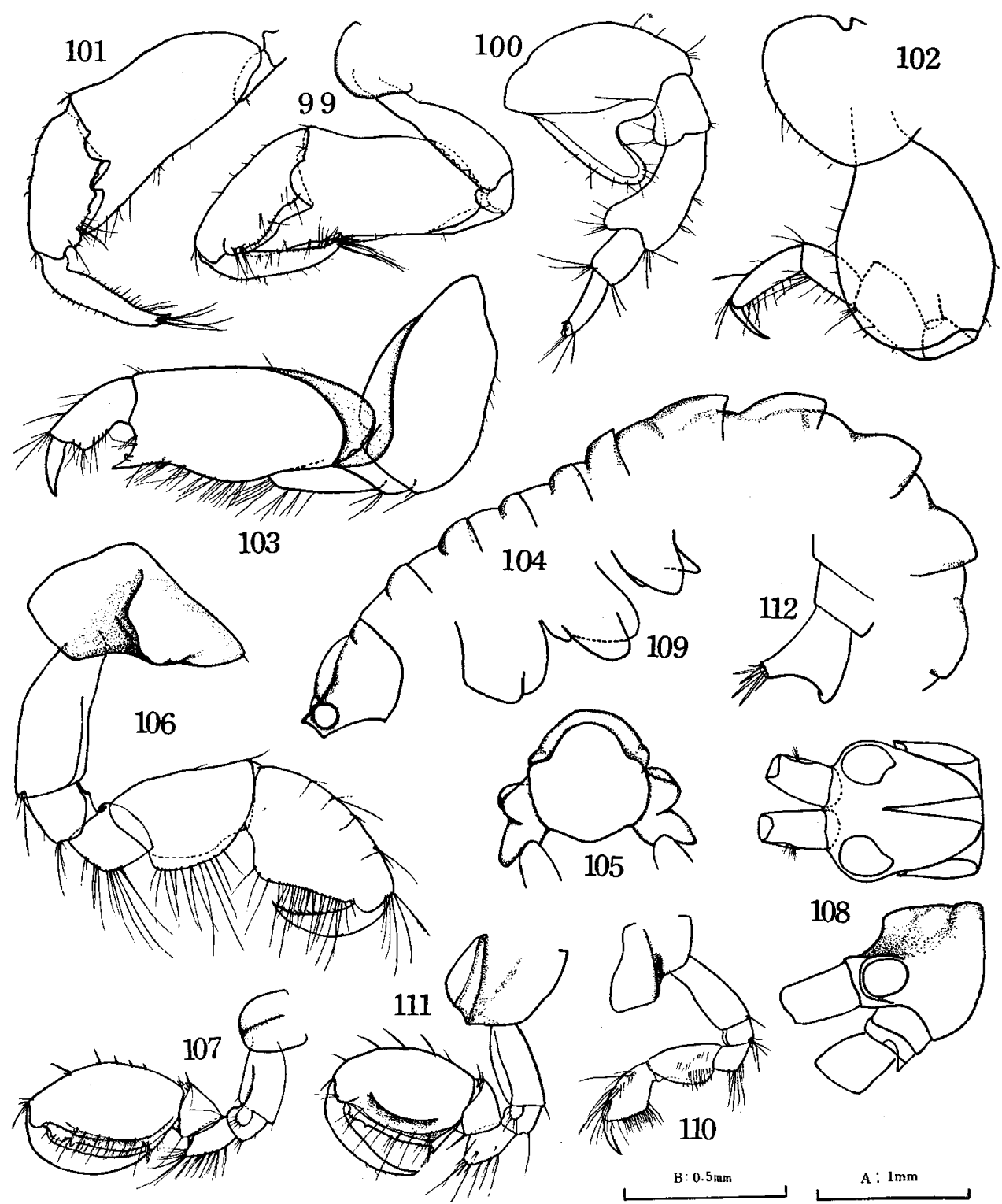

K. Nagata: Benthic Gammaridean Amphipoda from Zostera Region. 